\title{
PENINGKATAN NILAI GIZI DAN DAYA TERIMA SENSORIS PADA TEMPE BIJI KECIPIR (Psophocarpus tetragonolobus L) DENGAN PENAMBAHAN BIJI WIJEN
}

\author{
Arif Prashadi Santosa, Bambang Nugroho dan Apriliyanti Ningtiyas \\ Program Studi Agroteknologi, Fakultas Pertanian, Universitas Muhammadiyah Purwokerto \\ e-mail: arifpras.santosa@gmail.com
}

\begin{abstract}
This study aimed to find out the effect of adding sesame seeds toward the nutrition properties tested with proximate and sensory analyisis of winged bean seeds. The research design used was Randomized Complete Design with three levels, namely: W1: 5\% of 100 grams of weight of winged seeds, W2: 10\% of 100 grams of weight of winged seeds, W3: 15\% of 100 grams of weight of winged seeds. The results showed that the addition of sesame seeds $(W)$ significantly affected the proximate analysis on variables (ash, fat, crude fiber and $\mathrm{HCN}$ ) and the sensory analysis on variables (texture and aroma). The best treatment in proximate and sensory analysis was the $15 \%$ sesame seeds treatment addition based on protein content 30,53\%, HCN 0.02mg / 100g, moisture content $20.06 \%$, ash content $2.64 \%$, fat $11.80 \%$, coarse fiber $6.49 \%$ and carbohydrate by difference $35.30 \%$; with a preference value of 2.69 (rather dull), texture 2.67 (rather hard), smell 2.31 (bad smell), taste 2.86 (tasteless), appearance 3.26 (rather compact) and preference 2.34 (rather like).
\end{abstract}

Keywords: Winged Seeds Tempeh, Sesame Seeds, Proximate, Sensory.

\section{PENDAHULUAN}

\section{Latar Belakang}

Tempe merupakan makanan tradisional khas Indonesia, yang digemari oleh semua kalangan, baik dari anak-anak sampai kakek nenek. Tempe merupakan hasil fermentasi biji-bijian oleh beberapa jamur diantaranya adalah jamur Rhizopus oligosporus, Rhizopus oryzae atau Rhizopus stolonifer yang membentuk padatan kompak berwarna putih. Tempe mengandung berbagai nutrisi seperti protein, karbohidrat, lemak dan mineral yang sangat baik untuk tubuh (Maryanto, 2017).

Tempe yang diproduksi saat ini hampir semua berasal dari biji kedelai, dimana berdasarkan data yang dimiliki Primer Koperasi Tahu Tempe Indonesia (Primkopti) kebutuhan biji kedelai pertahun mencapai 2.2 juta ton. Sedangkan biji kedelai yang dihasilkan oleh petani hanya 0.6 juta ton dan untuk menutupi kebutuhan tersebut negara harus mengimport biji kedelai sekitar 1.6 juta ton dari Amerika Serikat (BSN, 2012). Sebenarnya banyak biji-bijian lain di Indonesia yang berpotensi untuk meningkatkan protein, dengan keadaan ini membuat para peneliti melakukan penelitian membuat tempe dari biji-biji lain seperti kara benguk (tempe benguk), biji lamtara (tempe lamtara), kacang tanah (tempe bungkil), dan biji kecipir (tempe kecipir) (Sarwono, 2002).

Dari beberapa jenis biji-bijian yang diteliti untuk pembuatan tempe, biji kecipirlah yang nilai gizinya mendekati nilai gizi biji kedelai. Nilai gizi biji kecipir per 100 gram meliputi: protein $29.8-$ 39.0 gram, energi 375 - 410 kal, karbohidrat 23.9 - 42.0 gram, lemak 15 - 20.4 gram, serat 3.7 16.1 gram, abu 3.3 - 4.9 gram dan air $8.7-24.6$ 
gram. Namun, dari hasil penelitian sebelumnya menyebutkan bahwa tempe biji kecipir yang dihasilkan memiliki bau "langu” sehingga kurang disukai oleh responden (Haryoto, 1995). Dan pada penelitian pembuatan susu biji kecipir pun memiliki kendala yang sama yaitu bau "langu" pada susu, adapun perlakuan yang digunakan untuk menghilangkan bau "langu” pada susu biji kecipir dengan penambahan biji wijen dan lama perebusan. Hasilnya pada penggunaan biji wijen 95 gram dari 1000 gram biji kecipir, bau "langu” pada susu biji kecipir tidak tercium (Wirnaningsih, 2014).

Menurut Haryoto (1996) biji wijen (Sesamum indicum) merupakan salah satu bahan pembantu yang berfungsi menghilangkan bau "langu". Dimana biji wijen yang telah disangrai mengeluarkan minyak yang beraroma sangat harum dan gurih. Minyak biji wijen juga berperan sebagai pengikat aroma dan katalisator, sehingga bau "langu" dapat dihilangkan. Namun belum ada penelitian mengenai pengaruh gizi dan sensiori terhadap penambahan biji wijen pada pembuatan tempe biji kecipir Sehingga perlunya analisis proksimat dan sensoris yang disesuaikan dengan syarat mutu tempe kedelai (SNI 3144:2015) (BSN, 2015).

\section{METODOLOGI PENELITIAN}

Penelitian dilaksanakan selama 3 bulan dimulai dari bulan Maret sampai dengan Mei 2018 di Laboratorium Agroteknologi Dasar Fakultas Pertanian Universitas Muhammadiyah Purwokerto dan Laboratorium Teknologi Pertanian Universitas Jendral Soedirman, Purwokerto.

\section{Bahan dan Alat}

\section{Bahan}

Biji kecipir, biji wijen, ragi merk "Raprima" 0.2\%, air, larutan asam klorida $(\mathrm{HCl}) 8 \mathrm{M}$, petroleum eter, larutan perak nitrat $\left(\mathrm{AgNO}_{3}\right)$ $0.1 \mathrm{M}$, aquades, batu didih, kalium sulfat $\left(\mathrm{K}_{2} \mathrm{SO}_{4}\right)$ bebas nitrogen, larutan katalis tembaga $\left(\mathrm{CuSO}_{4} .5 \mathrm{H}_{2} \mathrm{O}\right)$ bebas nitrogen $0.05 \mathrm{~g} / \mathrm{mL} \mathrm{H}_{2} \mathrm{O}$, Asam sulfat $\left(\mathrm{H}_{2} \mathrm{SO}_{4}\right)$ pekat bebas nitrogen, larutan natrium hidroksida $(\mathrm{NaOH}) 30 \%$, larutan indicator fenolftalein (PP) $1 \%$, larutan asam borat $\left(\mathrm{H}_{3} \mathrm{BO}_{3}\right)$ $4 \%$, larutan asam klorida $\mathrm{HCl} 0.1 \mathrm{~N}$, Anti buih, larutan asam sulfat $\left(\mathrm{H}_{2} \mathrm{SO}_{4}\right)$, larutan natrium hidroksida $(\mathrm{NaOH})$, kertas lakmus $\mathrm{AgNO}_{3} 0.02 \mathrm{~N}$ $20 \mathrm{ml}, \mathrm{HNO}_{3} 1 \mathrm{ml}$, sampel, tempe kedelai dan air mineral.

\section{Alat}

Panci, kompor, nampan, mangkuk plastik, wajan, serok, sendok, plastik tebal, tusuk gigi, timbangan, sealer, stopwatch, kamera, label, Koran, alat tulis, cawan, oven vakum, desikator, tanur, penangas air, penangas listrik, neraca analitik dengan ketelitian $0.1 \mathrm{mg}$, pengaduk, gelas piala, arloji, gelas arloji, kertas saring bebas lemak, pipet tetes, thimble ekstraksi, alat Soxhlet lengkap, alat destilasi Kjeldahl, alat destruksi, alat penghalus, saringan 1mm, Erlenmeyer $600 \mathrm{ml}$, pendingin balik, kertas saring tak berabu, spatula, steam distillation, Erlenmeyer, krus Gooch, kalkulator, piring plastik, plastik wrap, pisau plastik dan borang penelitian. 
Tabel 1. Analisis Proksimat dan Sensoris pada Tempe Biji Kecipir

\begin{tabular}{llc}
\hline No & Pelaksanaan penelitian & Metode \\
\hline 1. & Analisis proksimat & \\
& Kadar Air & Metode oven vakum (BSN, 2015) \\
& Kadar Abu & Metode tanur (BSN, 2009) \\
& Kadar Lemak & Metode soxhlet (BSN, 2015) \\
& Kadar protein & Metode kjeldahl (BSN, 2015) \\
& Kadar serat kasar & Metode gravimetri (BSN, 2015) \\
& Kadar HCN & Metode distilasi uap (AOAC, 1984) \\
& Karbohidrat by difference & Perhitungan kasar (Winarno, 1992) \\
2. & Analisis Sensoris (Warna, & Metode uji mutu tempe kedelai \\
& Tekstur, Aroma/bau, Rasa, & (Anonim, 2006) dengan 5 taraf \\
& Kenampakan dan Kesukaan) & \\
\hline
\end{tabular}

\section{Rancangan Percobaan}

Rancangan penelitan yang digunakan adalah Rancangan Acak Lengkap (RAL) faktorial. Dimana faktor pelakuannya adalah:

Faktor 1: Penambahan biji wijen yang digunakan (W) dengan tiga taraf.

W1: 5\% dari 100 gram berat biji kecipir.

W2: $10 \%$ dari 100 gram berat biji kecipir.

W3: $15 \%$ dari 100 gram berat biji kecipir.

dengan 3 kali ulangan, sehingga diperoleh 9 unit percobaan.

Uji yang dilakukan adalah Uji proksimat yang terdiri dari uji

\section{Pelaksanaan Penelitian}

Sebelum pelaksanaan penelitain, terlebih dahulu dilakukan pra-penelitian untuk menentukan lama waktu perebusan. Lama waktu erebusan yang digunakan adalah 60 menit yang dilakukan dengan dua kali perebusan, sebelum pengupasan dan setelah pengupasan biji kecipir. Untuk analisis yang diujikan dapat dilihat pada Tabel 1.

\section{Analisis Data dan Pengujian Hipotesis}

Analisis data hasil rata-rata analisis proksimat dan sensoris menggunakan Uji F 5\% (Uji Anova dengan tingkat kepercayaan $95 \%$ untuk mengetahui keragamannya) dan dilanjut dengan uji lanjut DMRT (Duncan Multipe Range Test).

\section{HASIL DAN PEMBAHASAN}

a. Kadar Air

Air merupakan hal yang penting pada suatu bahan pangan, kadar air dalam bahan dapat mendeteksi nilai keawetan bahan pangan dan dapat mempengaruhi penampakan, tekstur, serta cita rasa suatu bahan pangan (Winarno, 1992). Kadar air dari perlakuan penambahan biji wijen (W) tidak berpengaruh nyata pada kadar air. hal ini dapat dilihat pada Tabel 2. Perlakuan penambahan biji wijen pada tempe biji kecipir memiliki nilai kadar air yang sudah sesuai dengan syarat mutu tempe kedelai (SNI 3144:2015) dimana kadar air maksimal 65\% (BSN, 2015). 
Tabel 2. Rata-rata dan Notasi Hasil Analisis Proksimat Tempe Biji kecipir (Posphocarpus tetragolobus L) dengan Perlakuan penambahan Biji Wijen (Sesammum indicum) dan Variasi Lama Perebusan.

\begin{tabular}{clllllll}
\hline \multicolumn{2}{c}{ Perlakuan } & \multicolumn{5}{c}{ Variabel Pengamatan } \\
\hline $\begin{array}{c}\text { Penambahan Biji } \\
\text { Kijen }\end{array}$ & $(\%)$ & $\begin{array}{l}\text { K. Abu } \\
(\%)\end{array}$ & $\begin{array}{l}\text { K. Lemak } \\
(\%)\end{array}$ & $\begin{array}{l}\text { K. Protein } \\
(\%)\end{array}$ & $\begin{array}{l}\text { K. Serat } \\
(\%)\end{array}$ & $\begin{array}{l}\text { K. HCN } \\
(\mathrm{mg} / 100 \mathrm{~g})\end{array}$ & $\begin{array}{l}\text { Karbohidrat } \\
(\%)\end{array}$ \\
\hline W1 & $19.96 \mathrm{tn}$ & $2.67 \mathrm{~b}^{*}$ & $11.37 \mathrm{a}$ & $30.63 \mathrm{tn}$ & $6.14 \mathrm{a}$ & $0.04 \mathrm{~b}$ & $34.94 \mathrm{tn}$ \\
W2 & $19.93 \mathrm{tn}$ & $2.40 \mathrm{a}$ & $11.47 \mathrm{a}$ & $30.37 \mathrm{tn}$ & $6.32 \mathrm{~b}$ & $0.03 \mathrm{ab}^{*}$ & $35.93 \mathrm{tn}$ \\
W3 & $20.06 \mathrm{tn}$ & $2.64 \mathrm{~b}^{*}$ & $11.80 \mathrm{~b}^{*}$ & $30.53 \mathrm{tn}$ & $6.49 \mathrm{c}^{*}$ & $0.02 \mathrm{a}^{*}$ & $35.30 \mathrm{tn}$ \\
\hline
\end{tabular}

Keterangan: Angka rata-rata yang diikuti oleh huruf yang sama pada satu kolom yang sama menunjukan tidak berpengaruh nyata pada DMRT 5\%. tn : Tidak berpengaruh nyata

b. Kadar Abu

Kadar abu merupakan kadar yang mengambarkan banyaknya mineral norganik dalam suatu bahan. Sekitar $96 \%$ bahan makanan terdiri dari bahan organik dan air sehingga sisanya hanya unsur mineral anorganik (Tarigan, 2010).

Perlakuan penambahan biji wijen (W) pada penelitian pembuatan tempe memiliki hasil berpengaruh nyata pada kadar abu. Dimana Kadar abu dari biji wijen itu sendiri 4.5-6.5\% (Schuster, 1a.

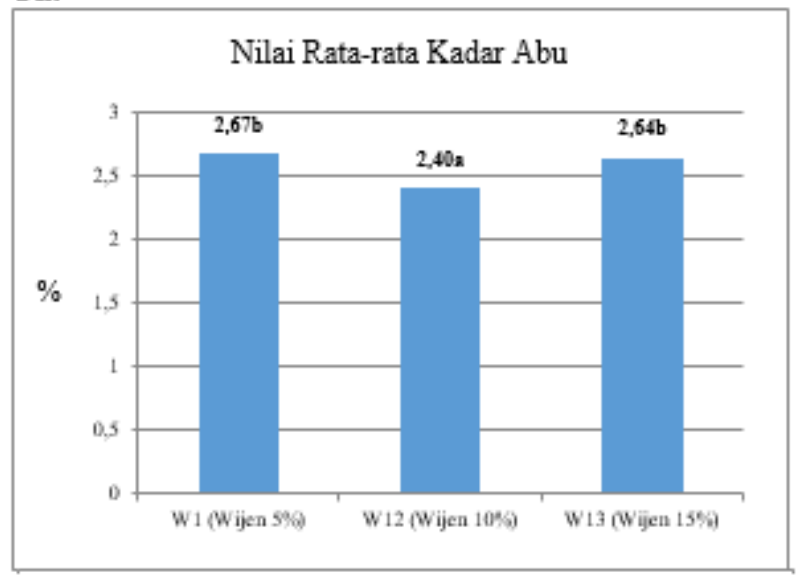

1c.

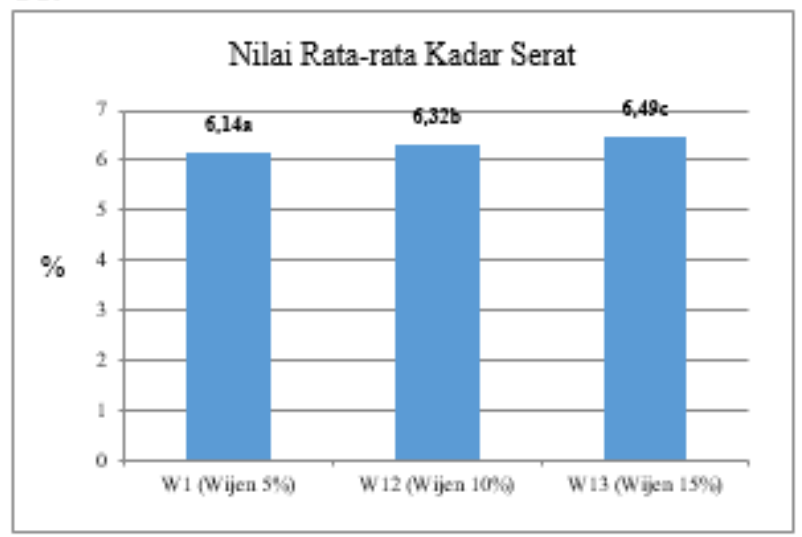

$1 b$.

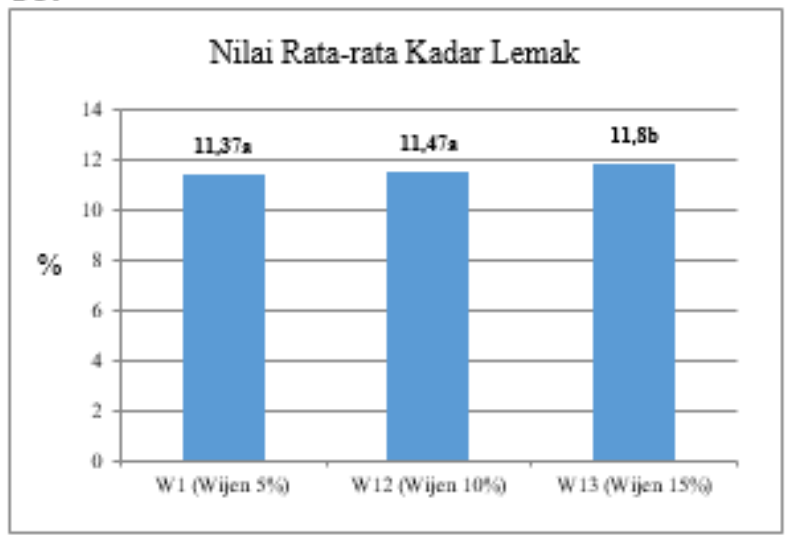

$1 d$.

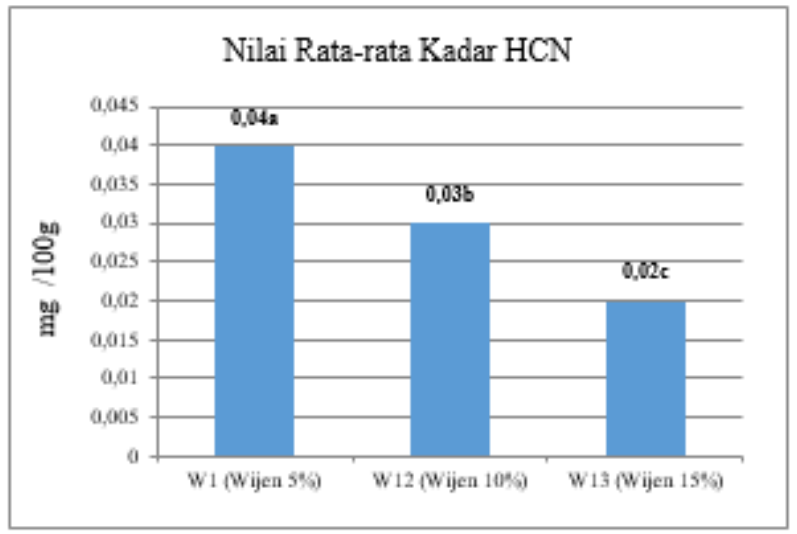

Gambar 1. Hasil Uji Proximat Tempe Biji Kecipir dengan Perlakuan Penambahan Biji Wijen 
1992). Dan hasil nilai rata-rata kadar abu pada perlakuan penembahan biji wijen (W) dapat dilihat pada gambar 1a.

Nilai terbesar pada perlakuan penambahan biji wijen 5\% (W1), namun adanya penurunan nilai kadar abu pada perlakuan penambahn biji wijen 10\% (W2) dan kenaikan nilai kadar abu pada perlakuan penambahan biji wijen 15\% (W3), hal ini terjadi karena adanya titik jenuh pada range penambahan biji wijen (Romadhona et al, 2015). Kadar abu tempe biji kecipir yang ditambahkan biji wijen, belum memenuhi standar SNI 3144:2015 menegenai Tempe yang mensyaratkan kadar abu maksimal 1.5\% (BSN, 2015).

\section{c. Kadar Lemak}

Lemak merupakan sumber energi bagi tubuh, yang tidak larut dalam air dan berasal dari tumbuh-tumbuhan atau hewan (Buckle, 1987). Perlakuan penambahan biji wijen (W) pada variabel kadar lemak berpengaruh nyata pada kadar lemak, dimana dapat dilihat pada gambar $1 b$.

Biji wijen memiliki nilai rata-rata kandungan lemak yang tinggi sebesar 50-53\% (Weiss, 1971). Hal ini memungkinkan penambahan kandungan lemak pada tempe biji kecipir. Pada perlakuan penambahan biji wijen 5\% (W2) dan perlakuan penambahan biji wijen 10\% (W3) memiliki nilai tidak sebesar perlakuan penambahan biji wijen 15\% (W1) karena adanya proses sangrai pada biji wijen akan meningkatkan kandungan lemak pada biji wijen tersebut karena adanya titik jenuh pada range penambahan biji wijen (Romadhona et al, 2015).

\section{d. Kadar Protein}

Protein merupakan kandungan pada suatu bahan yang sangat penting bagi tubuh, karena sebagai sumber bahan bakar dalam tubuh yang berfungsi sebagai zat pembangu dan pengatur (Winarno, 1992). Kadar protein yang didapat dari adanya perlakuan penambahan biji wijen (W) tidak berpengaruh nyata seperti yang tersaji pada Tabel 2.. Tingginya kadar protein tempe biji kecipir sudah sesuai dengan syarat mutu tempe kedelai (SNI 3144:2015) dimana nilai minimal protein 15\% (BSN, 2015).

\section{e. Kadar Serat Kasar}

Serat merupakan istilah umum dari campuran heterogen komponen pangan yang tidak dicerna dalam usus halus termasuk zat dinding sel tanaman (selulosa, hemiselulosa, pektin dan lignin) serta polisakarida interseluler gum dan mucilage (Dewanti et al, 2017). Pada perlakuan penambahan biji wijen (W) berpengaruh nyata, seperti dapat dilihat pada gambar 1c.

Semakin banyak penambahan biji wijen (W) semakin meningkatnya nilai kadar serat kasar tempe biji kecipir. Dimana nilai rata-rata kadar serat kasar yang tertinggi tertera pada gambar 4.11 adalah penambahan biji wijen $15 \%$ (W3) hal ini karena kadar serat kasar yang terkandung pada biji wijen 7-8\% (Schuster, 1992).

\section{f. Kadar HCN}

$\mathrm{HCN}$ atau yang sering dikenal asam sianida, merupakan senyawa yang terdapat dalam makanan nabati terutama kacang-kacangan dan berpotensi terurai menjadi sifat yang beracun. HCN (Asam sianida) dapat dihilangkan apabila 
bahan dihancurkan, dikunyah, diiris atau dirusak sehingga asam sianida ( $\mathrm{HCN})$ dapat teroksidasi (Budiyanto, 2001). Pada perlakuan penambahan biji wijen (W) berpengaruh nyata pada kadar $\mathrm{HCN}$. Dimana nilai rata-rata kadar $\mathrm{HCN}$ terkecil pada perlakuan penambahan biji wijen 15\% (W3). Hal ini terjadi adanya vitamin E yang banyak terkandung pada biji wijen yang bermanfaat sebagai antioksidan (Lamid, 1995). Penurunan nilai rata-rata kadar $\mathrm{HCN}$ terhadap penambahan biji wijen (W) tertera pada gambar 1d.

\section{g. Karbohidrat by difference}

Karbohidrat merupakan sumber kalori utama bagi makhluk hidup. Pada analisis proksimat karbohidrat by difference ditentukan dengan cara perhitungan 100\% - (Protein + lemak + abu + air $)$ (Winarno, 1992). Dari hasil yang didapat perlakuan penambahan biji wijen (W) tidak berpengaruh nyata, nilai rata-ratanya dapat dilihat pada Tabel 2.

\section{Analisis Sensoris}

Berdasarkan hasil dari analisis sensoris yang dilakukan diperoleh data yang kemudian diuji dengan uji F 5\% dan dilanjut dengan uji DMRT, sehingga diperoleh yang dapat dilihat pada tabel 3.

\section{Warna}

Warna adalah salah satu bentuk visual dari sebuah produk yang diamati dengan menggunakan indera penglihatan dan daya tarik suatu produk sangat dipengaruhi oleh warna serta bagian yang tak terpisahkan dalam penilaian mutu (Zuraidah, 2005). Hasil warna yang diperoleh dari analisis menunjukkan tidak berpengaruh nyata pada perlakuan penambahan biji wijen (W), dimana mendapat nilai rata-rata 3 (Agak Kusam). Dan warna tempe kecipir yang dihasilkan sesuai dengan syarat mutu tempe kedelai (SNI 3144:2015), dimana warna tempe yang dihasilkan haruslah putih merata pada seluruh permukaan (BSN, 2015).

\section{a. Tekstur}

Tekstur pada tempe sangat berpengaruh pada selera kesukaan konsumen, dimana tempe yang baik tidak bertekstur keras dan tidak bertekstur lembek. Penginderaan tekstur berasal dari sentuhan yang ditangkap oleh seluruh permukaan kulit (Soewarno, 1985). Berdasarkan dari hasil uji lanjut penambahan biji wijen (W), berpengaruh nyata pada variable tekstur.

Berdasarkan gambar 2a. penamban biji wijen $5 \%$ (W1), $10 \%$ (W2) dan 15\% (W3) memiliki

Tabel 3. Rata-rata dan Notasi Hasil Analisis Sensoris Tempe Biji Kecipir (Psophocarpus tetragonolobus L) dengan Perlakuan Penambahan Biji Wijen (Sesamum indicum) dan Variasi Lama Perebusan

\begin{tabular}{ccccccc}
\hline Perlakuan & \multicolumn{5}{c}{ Variabel Pengamatan } \\
\hline $\begin{array}{c}\text { Penambahan Biji } \\
\text { Wijen }\end{array}$ & Warna & Tekstur & Aroma/Bau & Rasa & Kenampakan & Kesukaan \\
\hline W1 & $2.57 \mathrm{tn}$ & $3.08 \mathrm{~b}^{*}$ & $1.91 \mathrm{a}$ & $2.61 \mathrm{tn}$ & $2.98 \mathrm{tn}$ & $2.12 \mathrm{tn}$ \\
W2 & $2.46 \mathrm{tn}$ & $2.90 \mathrm{ab}^{*}$ & $2.13 \mathrm{ab}^{*}$ & $2.83 \mathrm{tn}$ & $3.03 \mathrm{tn}$ & $2.25 \mathrm{tn}$ \\
W3 & $2.69 \mathrm{tn}$ & $2.67 \mathrm{a}$ & $2.31 \mathrm{~b}^{*}$ & $2.86 \mathrm{tn}$ & $3.26 \mathrm{tn}$ & $2.34 \mathrm{tn}$ \\
\hline
\end{tabular}

Keterangan: Angka rata-rata yang diikuti oleh huruf yang sama pada satu kolom yang sama menunjukan tidak berpengaruh nyata pada DMRT 5\%. tn : Tidak berpengaruh nyata 
nilai kesukaan hampir sama pada tekstur, tetapi penambahan biji wijen 5\% (W1) yang memiliki nilai kesukaan tekstur tertinggi 3.08 (agak keras). Menurut Gracia (2009), tekstur pada makanan sangat dipengaruhi oleh kadar air, kadar lemak, jumlah dan jenis karbohidrat serta protein yang menyusunnya.

Selain itu tekstur (kekerasan) tempe dipengaruhi oleh pertumbuhan misellia yang menutupi permukaan tempe, sehingga memberi tekstur yang kokoh (Susanto, 1999). Dan misellia akan meningkat kerapatan masa antar biji sehingga membentuk suatu massa yang kompak dan mengurangi rongga udara didalam tempe (Sukardi dan Purwaningsih, 2008).

\section{b. Aroma/Bau}

Aroma adalah bau yang ditimbulkan oleh rangsangan kimia yang tercium oleh syaraf-syaraf olfaktori yang berada dalam rongga hidung ketika makanan masuk ke dalam mulut (Winarno, 2004). Aroma/bau yang dihasilkan oleh biji kecipir sangatlah kuat sehingga tempe biji kecipir yang dihasilkan tanpa penambahan bahan lain sangat berbau "langu”. Pada penambahan biji wijen (W) berpengaruh nyata dimana dapat dilihat pada gambar $2 b$.

Perlakuan penambahan biji wijen yang semakin banyak dapat mengurangi bau "langu" pada tempe biji kecipir, dimana perlakuan penambahan biji wijen $15 \%$ (W3) memiliki nilai rata tertinggi 2.31 (agak berbau langu) karena biji wijen yang merupakan bahan pembantu atau salah satu bumbu yang memiliki aromatik yang dapat mengurangi bau "langu” pada tempe biji kecipir dan sifat minyak biji wijen yang dapat mengikat aroma (Marliani, 2008). Dan menurut Haryoto (1996) biji wijen setelah melalui proses sangrai memiliki aroma yang sangat harum sehingga dapat menetralisir aroma "langu” dari biji kecipir.

Bau langu dari biji kecipir ini menyebabkan tempe biji kecipir yang sudah ditambahkan biji wijen kurang sesuai dengan syarat mutu tempe kedelai (SNI 3144:2015) karena aroma/bau yang didapat dari tempe haruslah khas tempe tanpa adanya aroma/bau amoniak (BSN, 2015).
$2 \mathrm{a}$.

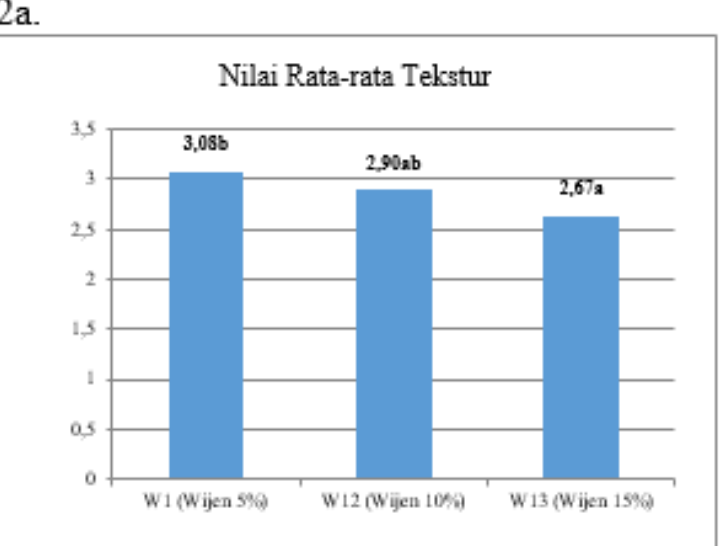

2 b.

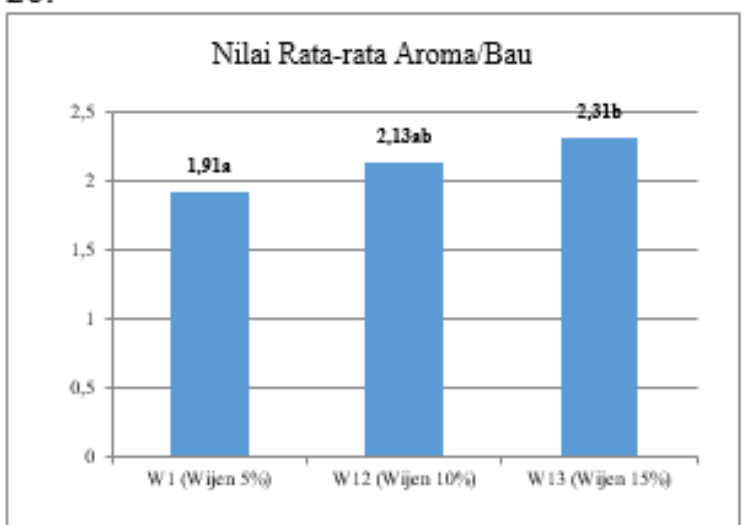

Gambar 2. Hasil Uji Sensoris Tempe Biji Kecipir dengan Perlakuan Penambahan Biji Wijen 
c. Rasa

Rasa yang didapat dari tempe adalah hambar atau berasa khas tempe. Rasa pada saat pengujian melibatkan panca indera lidah. Agar suatu senyawa dapat dikenali rasanya, senyawa tersebut harus dapat mengadakan hubungan dengan mikrovilus dan implus yang akan dikirim kepusat syaraf. Dan setiap orang memiliki batas konsentrasi yang berbeda terhadap rasa (Winarno, 1997).

Perlakuan penambahan biji wijen (W) tidak berpengaruh nyata secara indrawi dengan nilai rata-rata 2,72 (hambar) dan sudah sesuai dengan syarat mutu tempe kedelai (SNI 3144:2015) dimana rasa tempe adalah normal/hambar tidak ada rasa pahit (BSN, 2015).

\section{d. Kenampakan}

Penilai kenampakan pada tempe biji kecipir dilihat dari kekompakan antar biji kecipir. Kekompakan tempe terjadi akibat miselliamisellia yang menghubungkan antar biji dan jika diiris tetap utuh tidak mudah rontok sesuai dengan syarat mutu tempe kedelai (SNI 3144:2015) (BSN, 2015). Pada penambahan biji wijen (W) tidak berpengaruh nyata terhadap kenampakan tempe biji kecipir. Menurut Winarno (1988), kenampakan merupakan parameter uji sensoris yang paling penting karena sifat sensorik yang pertama kali dilihat oleh konsumen. Pada umumnya konsumen memilih makanan yang memiliki kenampakan menarik.

Nilai rata-rata kenampakan 3.09 (kompak). Hal ini terjadi adanya penambahan biji wijen yang tidak terlalu banyak sehingga pertumbuhan misellia tidak terhambat dan hasil dari tempe biji kecipir sudah sesuai dengan syarat mutu tempe kedelai (SNI 3144:2015) dimana pada tekstur tempe biji kecipir yang kompak jika diiris tetap utuh (tidak rontok) (BSN, 2015).

e. Kesukaaan

Kesukaan pada perlakuan penambahan biji wijen tidak berpengaruh nyata terhadap tempe biji kecipir. Kesukaan atau daya terima konsumen terhadap suatu produk makanan tertentu dipengaruhi oleh berbagai faktor, diantaranya faktor lingkungan, sosial budaya, kondisi emosional dan pengaruh dari produk itu sendiri. Keberadaan daya terima itu sendiri dapat dikaitkan dengan tingkat kepuasan konsumen, sehingga semakin baik daya terima suatu produk berarti semakin tinggi pula tingkat kepuasan dalam mengkonsumsi produk tersebut (Soediatama, 1993).

\section{KESIMPULAN}

Berdasarkan hasil penelitian yang dilaksanakan dapat disimpulkan sebagai berikut: Perlakuan penambahan biji wijen berpengaruh nyata terhadap analisis proksimat pada variabel kadar abu, kadar lemak, kadar serat kasar, dan kadar HCN dan. Sedangkan terhadap analisis sensoris berpengaruh nyata pada variabel tekstur dan aroma/bau

\section{DAFTAR PUSTAKA}

Anonim. 2006. Pengujian Organoleptik (Evaluasi Sensori) dalam Indusri Pangan.ebook pangan.com.

AOAC, 1984. Official Methods of Analysis. Association of Official. Agricultural Chemists. Washington DC. 
BSN. 2009. SNI Tempe Kedelai (SNI 3144:2009). Jakarta: www.bsn.go.id.

BSN. 2012. Tempe: Persembahan Indonesia untuk Dunia. Jakarta: BSN 2012.

BSN. 2015. SNI Tempe Kedelai (SNI 3144:2015). Jakarta:www.bsn.go.id.

Buckle, K.A. 1987. Ilmu Pangan. Jakarta: universitas Indonesia press.

Budiyanto. 2001. Buku pedoman penyuluhan dan pelatihan gizi. Jakarta: Depkes RI.

Dewanti, T.W. Wijayanti, $\mathrm{N}$ dan Panca, N.I.N. 2017. Pangan Fungsional Aspek Kesehatan, Evaluasi dan Regulasi. Malang: UB Media

Gracia, C, S dan Haryanto, B. 2009. Kajian Formula Biskuit Jagung dalam Rangka Substitusi Tepung Terigu. Jurnal Teknologi dan Industri Pangan. Vol XX No.1.

Haryoto. 1995. Tempe dan Kecap Kecipir.Yogyakarta: Kanisius.

Haryoto. 1996. Susu dan Yoghurt Kecipir. Yogjakarta: Kanisius.

Lamid, A. 1995. Vitamin E sebagai Antioksidan. Media Litbangkes. Vol 5(1). Hal 14-16

Marliani, L. 2008. Wijen Raja Minyak dari Ethiophia. [Online]. Tersedia: http://www.sinarharapan.co.identifikasi/iptek/k esehata n/2004/0310/kes.2.html. Diakses [30 Juni 2018].

Maryanto, H. 2017. Petunjuk Praktikum Bioteknologi. Purwokerto. Program Studi Pendidikan Biologi. FKIP. UMP.

Romadhona, S., Lutfi, M., dan Yulianingsih Y. 2015.Studi Metodedan Lama Pemanasan pada Ekstraksi Minyak Biji Wijen (Sesamum indicum L). Jurusan Keteknikan Pertanian - Fakultas Teknologi Pertanian Universitas Brawiaya. Jurnal Bioproses Komoditas Tropis. Vol. 3 No.1,50.

Sarwono, B. 2002. Membuat Tempe dan Oncom. Jakarta: penebar Swadaya.

Schuster W.H. 1992. Olpflanze in eropa. DL: $G$ Verlag, Frankfrut-am-main. Kategori: Rintisan Bertopik Makanan. [Online].Tersedia http://id.wikipedia.org/wiki/ wijen. Diakses [28 Desember 2017].

Sediaoetama A. D. 1999. Ilmu Gizi. Jakarta: Dian Rakyat.

Soewarno, S. 1985. Penilaian Organoleptik. Jakarta: Bhrathara Karya Aksara.
Sukardi, W., dan Purwaningsih, I. 2008. Uji Coba Penggunaan Inokulum Tempe dari Kapang Rhizopus oryzae dengan Substrat Tepung beras dan Ubi Kayu pada Unit Produksi Tempe Sanan Kodya Malang. Jurnal Teknologi Pertanian. Vol 9 (9):207-215.

Susanto, T.B. 1999. Rekayasa Perbaikan Teknologi Pembuatan Tempe Kedelai dan Pengembangannya pada Industri Tempe Generasi Kedua dan Ketiga. Rangkuman Hasil Penelitian. Malang: Lemabaga Penelitian Universitas Brawijaya.

Tarigan, J. P. 2010. Pra Rancangan Pabrik Pembuatan Kappa Karagenan dari Kappaphycus Alvarezii dengan Proses Murni dengan Kapasitas Produksi Ton/Jam. Tugas Akhir. Departemen Teknik Kimia Fakultas Teknik Universitas Sumatera Utara. Medan.

Weiss, E.A. 1971. Castor, Sesame, and Safflower. London: Leonard Hill.

Winarno, F.G. 1988. Kedelai Bahan Pangan Masa Depan. Bogor: Pusbangtepa IPB.

Winarno, F.G. 1992. Kimia Pangan dan Gizi. Jakarta: Gramedia Pustaka Utama.

Winarno, F. 1997. Kimia Hasil Pertanian. Jakarta: Gramedia Pustaka Utama.

Winarno, F.G. 2004. Keamanan Pangan. Bogor: M-Brio Press.

Wirnaningsih, L.K. 2014. Pembuatan Susu Kecipir Dengan Variasi Berat Wijen dan.Lama Perebusan. Fakultas Teknologi dan Indusrti Pangan, Universitas Slamet Riyadi Surakarta.

Zuraidah. 2005. Pemanfaatan Wortel (Daucus carota) dalam Pembuatan Mie Basah Serta Analisa Mutu Fisik dan Mutu Gizinya. [Online].

Tersedia: http://repository.usu.ac.id. Diakses [30 Juni 2018]. 